\title{
Changing Political Economy of the Hong Kong Media
}

Francis L. F. Lee

\section{CpenEdition}

\section{Journals}

Electronic version

URL: https://journals.openedition.org/chinaperspectives/8009

DOI: 10.4000/chinaperspectives.8009

ISSN: 1996-4617

\section{Publisher}

Centre d'étude français sur la Chine contemporaine

Printed version

Date of publication: 1 September 2018

Number of pages: 9-18

ISSN: 2070-3449

\section{Electronic reference}

Francis L. F. Lee, "Changing Political Economy of the Hong Kong Media", China Perspectives [Online], 2018/3 | 2018, Online since 01 September 2018, connection on 21 September 2021. URL: http:// journals.openedition.org/chinaperspectives/8009; DOI: https://doi.org/10.4000/chinaperspectives 8009 


\title{
Changing Political Economy of the
} Hong Kong Media

\author{
FRANCIS L. F. LEE
}

\begin{abstract}
Most observers argued that press freedom in Hong Kong has been declining continually over the past 15 years. This article examines the problem of press freedom from the perspective of the political economy of the media. According to conventional understanding, the Chinese government has exerted indirect influence over the Hong Kong media through co-opting media owners, most of whom were entrepreneurs with ample business interests in the mainland. At the same time, there were internal tensions within the political economic system. The latter opened up a space of resistance for media practitioners and thus helped the media system as a whole to maintain a degree of relative autonomy from the power centre. However, into the 2010s, the media landscape has undergone several significant changes, especially the worsening media business environment and the growth of digital media technologies. These changes have affected the cost-benefit calculations of media ownership and led to the entrance of Chinese capital into the Hong Kong media scene. The digital media arena is also facing the challenge of intrusion by the state.
\end{abstract}

KEYWORDS: press freedom, political economy, self-censorship, digital media, media business, Hong Kong.

$\mathrm{T}$ wo decades after the handover, many observers, academics, and journalists would agree that press freedom in Hong Kong has declined over time. The titles of the annual reports by the Hong Kong Journalists Association (HKJA) in the last decade regularly express concern about threats to freedom of expression and of the press, e.g. "Hong Kong media faces serious harassment and self-censorship" (HKJA 2015), "Beijing turns the screws on Hong Kong media" (HKJA 2017). In the World Press Freedom Index of Reporters Without Borders, Hong Kong's ranking fell from 18 in 2002 to 73 in 2017.(1)

However, press freedom is not entirely dead. Freedom House rated the Hong Kong press as "partly free" in 2017. As opposed to the mainland, there is no system of governmental pre-publication censorship. There has been continual negotiation between the media and political power (Lee 2000; Ma 2007) and journalistic resistance within media organisations (Au 2017; Lee and Chan 2009). Nevertheless, how effective can the negotiation and resistance be in the long run? Is the media system developing in ways favouring the defence or furthering the demise of press freedom?

This article attempts to address these questions by reviewing the changing political economy of the Hong Kong media. Two specifications are in order. First, given the concern with press freedom, the article focuses primarily on the news media. The article uses the terms news media and media largely interchangeably. However, because the news media are inextricably embedded in the larger media system, drawing a clean line between news and non-news media is unnecessary and can be misleading. Second, this article examines the question of press freedom from the political economy perspective. It does not directly address the much broader issue of freedom of speech, which would relate to additional issues such as the changing legal parameters of free speech in the city.

Following Mosco (2009), the political economic analysis of this article emphasises the structuration of the media system, i.e. the analysis sees the political economic structure as continually reproduced through interactions among various forces. The analysis consists of three main parts. The first part follows past scholarship to outline the ownership structure of the Hong Kong media system, while noting how several counteracting forces have prevented the media from succumbing totally to political power. The second part examines the changing media businesses and outlines the background for the growth of "direct investment" by Chinese capital in the Hong Kong media scene. The third part discusses the implications of digital transformation, including its impact on the mainstream media, the growth of alternative media, and how the state responds to the "digital challenge." The concluding section highlights the implications of the analysis.

Methodologically, this article draws upon data derived from multiple sources, including archival materials, news reports, media corporations' annual financial reports, data from the existing literature, and data from surveys of journalists and news readers available to the author. Similar to many political economic analyses of the media industry, the various data and materials were used to reconstruct a holistic account of the dynamic development of the media system in Hong Kong.

\section{From ownership structure to continual negotiation}

Although this article focuses on changes after the handover, it might help contextualise the discussion by starting with press freedom before 1997 . The colonial Hong Kong government had long established various harsh press laws. But the laws were seldom utilised to control the press, partly because of the need to avoid provoking China, and partly because the Hong Kong press in the immediate post-war decades focused mainly on Chinese politics instead of social and political affairs in Hong Kong. "Press freedom" was, for a long period of time, the freedom to criticise both the Communist regime in the PRC and the KMT regime in Taiwan as long as the colonial government was not challenged (Chan and Lee 1991).

1. Information is available at: https://rsf.org/en/ranking_table (accessed on 25 August 2018) 
Table 1 - Selected list of past or present owners or major shareholders of media organisations

\begin{tabular}{|l|l|l|l|}
\hline \multicolumn{1}{|c|}{ Name } & \multicolumn{1}{|c|}{ Origin } & \multicolumn{1}{|c|}{ Media position } & \multicolumn{1}{c|}{ Titles in political society } \\
\hline WANG Jing & Mainland & Major shareholder, ATV (until 2015) & CPPCC (2003-2013) \\
\hline LIU Changle & Mainland & Major shareholder, ATV (until 2007) & CPPCC (2003-2023) / GBS 2016 / SBS 2010 \\
\hline CHAN Wing-kee & Hong Kong & Major shareholder, ATV (until 2016) & $\begin{array}{l}\text { CPPCC (2003-2018)/ NPC (1993-2003) } \\
\text { GBM 2016 / GBS 2000 }\end{array}$ \\
\hline LI Ruigang & Mainland & Vice-Chairman, TVB (since 2016) & $\begin{array}{l}\text { Deputy secretary general of the Communist Party in Shanghai } \\
\text { (2011-2012) }\end{array}$ \\
\hline Henry CHENG & Hong Kong & Major shareholder, Cable TV (since 2017) & CPPCC (1993-2018) / GBS 2001 \\
\hline David YAU & Hong Kong & Major shareholder, Cable TV (since 2017) & CPPCC (2013-2023) \\
\hline Douglas WOO & Hong Kong & Major shareholder, Cable TV (until 2017) & $\begin{array}{l}\text { Member of Beijing Municipal People's Political Consultative } \\
\text { Conference (2013-2023) }\end{array}$ \\
\hline Peter WOO & Hong Kong & Founding Chairman, Cable TV (until 2017) & CPPCC (1998-2018) / GBS 1998 \\
\hline LI Ka Shing & Hong Kong & Owner, Metro Broadcast (under CK Hutchison Holdings) & GBM 2001 \\
\hline Victor LI & Hong Kong & Owner, Metro Broadcast (under CK Hutchison Holdings) & CPPCC (1998-2023) \\
\hline Richard LI & Hong Kong & Owner, NOW TV Chairperson, HK Economic Journal & $\begin{array}{l}\text { Member of Beijing Municipal People's Political Consultative } \\
\text { Conference (2013-2018) }\end{array}$ \\
\hline Charles HO & Hong Kong & Chairperson, Sing Tao News Corporation & CPPCC (1998-2023) / GBM (2014) \\
\hline FUNG Siu Por & Hong Kong & Chairman, HK Economic Times & GBS (2003) \\
\hline MA Ching-kwan & Hong Kong & Honorary Chairperson, Oriental Press Group Ltd. & CPPCC (2003-2013) \\
\hline MA Yun & Mainland & Major shareholder, SCMP (since 2016) & $\begin{array}{l}\text { Zhejiang Province People's Political Consultative Conference } \\
\text { (2008-2012) }\end{array}$ \\
\hline
\end{tabular}

Notes: Adopted and revised based on Ma (2007) and updated in 2017-2018. CPPCC = Chinese People's Political Consultative Conference; NPC = National People's Congress; $\mathrm{GBM}=$ Grand Bauhinia Medal; GBS = Gold Bauhinia Star; SBS = Silver Bauhinia Star

The situation changed in the 1980s when a "local society" was formed. But at the same time, the Sino-British negotiations and joint declaration on the future of Hong Kong resulted in a "dual power structure" in which the power and influence of China and Britain balanced out each other. The Hong Kong press thus enjoyed an unprecedented degree of freedom in the transition period (i.e. 1984-1997) (Chan and Lee 1991). Nevertheless, as the handover approached, China's influence increased, and the political economic structure of the Hong Kong media system also started to change.

\section{Ownership structure}

Major changes in media ownership began before the handover, and it was clear that co-opting media owners would be the most important means by which the Chinese government tamed the Hong Kong press. The purchase of South China Morning Post (SCMP) by Robert Kuok and the purchase of Chinese daily Ming Pao by Tiong Hiew King, both Malaysian tycoons, in 1993 and 1995 respectively, were among the most notable cases. The presumed economic logic behind these purchases is that being the owner of a Hong Kong news organisation provides the business person a kind of symbolic capital that can be used in exchange for social and political capital in the mainland. As a feature article by The Initium wrote:

[According to a former Ming Pao executive], after purchasing Ming Pao, Tiong Hiew King (...) indeed became someone local officials would treat seriously because of his identity as "the boss of Ming Pao." (2)

The former Ming Pao executive was also quoted as saying that Tiong purchased the newspaper at a loss, but Tiong did not mind because the real gain did not come from the media business. It is difficult for academics to document how the "real gain" can be materialised, but what the executive said at least illustrates the common understanding of the symbolic value of "being a Hong Kong media owner." In fact, over the years, some media outlets continued to attract business investment despite the losses they had sustained. The most obvious case is Asia Television Ltd. (ATV), one of the two free TV broadcasters in the city between the late 1970s and 2016, which continued to attract new investors during the 2000s despite having very low audience ratings and registering financial losses for years.

By the mid-2000s, most media organisations in Hong Kong were owned by business people with heavy business interests in the mainland. Fung (2007) described the situation as non-organisational concentration of ownership, i.e. the concentration of media into the hands of not a single corporation, but a group of business people sharing the same basic interest in appeasing the Chinese government.

The relationship between the media owners and the state can be partly indicated by the formal titles and political awards the state meted out to the media owners. Table 1 shows a select list of major media owners in Hong Kong and their titles in political society. For instance, Hong Kong media owners in the 12 $2^{\text {th }}$ session (2013-2018) of the Chinese People's Political Consultative Conference (CPPCC) include Charles Ho of Sing Tao News Corporation, Peter Woo of Wharf (parent corporation of Cable TV before May 2017),Victor Li of CK Hutchison Holdings (parent corporation of Metro Broadcast), and David Yau of Cable TV (after his joint purchase of the company in May 2017). $\mathrm{Ho}$, Li, and Yau remain members of CPPCC in the $13^{\text {th }}$ session (2018-2023).

Certainly, with vast interests and connections in the mainland, the aforementioned business tycoons would have gotten their titles and awards without owning media outlets. Table 1 does not show that media ownership

2. “張曉卿: 南洋華商的中國夢(三)” (Tiong Hiew King: Nanyang huashang de Zhongguo meng (san), Tiong Hiew King: The China dream of a Chinese merchant from the Southern sea (3)), The Initium, 12 August 2016, https://theinitium.com/article/20160812-mainland-tionghiewking3/ (accessed on 25 August 2018). 
leads to political recognition; it simply shows how media ownership is embedded in the web of state-business relations.

\section{Forms of control and censorship}

Ownership does not entail direct intervention into newsrooms by the owners, but it entails the possibility of intervention when needed. A case in point is Ming Pao's controversial change of chief editorship in early 2014, when the former chief editor was assigned to another role within the organisation, and veteran Malaysian journalist Chong Tien Siong was "parachuted" into Hong Kong to take up the post. Chong's lack of experience regarding Hong Kong led to questions about his suitability for the job. Many Ming Pao journalists worried that his arrival signified Tiong Hiew King's attempt to tighten his control of the newspaper. No matter what the real motivation was, such a move did not occur in the first 19 years after Tiong purchased Ming Pao. It occurred in 2014, when Hong Kong was embroiled in debate surrounding the plans of Occupy Central.

The most basic reason for the usual lack of direct intervention by owners is that leaders of large business corporations are unlikely to have time to do so. Yet media theorists have distinguished between allocative and operational control (Murdock 1982). Operational control refers to the control of the daily and frontline operations of the media organisations, whereas allocative control refers to the control of basic personnel and resource allocative decisions that set up the parameters for newsroom operations. Media owners can exercise allocative control even if they do not exercise operational control.

What the allocative and personnel decisions lead to is self-censorship and constitutive censorship. C. C. Lee defined self-censorship as "a set of editorial actions ranging from omission, dilution, distortion, and change of emphasis to choice of rhetorical devices by journalists, their organizations, and even the entire media community in anticipation of currying reward and avoiding punishments from the power structure" (Lee 1998: 57). Suspected cases of self-censorship occurred regularly after the handover, including the firing of media personnel known for their critical views toward the government and highly questionable treatment of sensitive stories (e.g. Cheung 2003; HKJA 2015). In surveys of Hong Kong journalists over the years, the percentage of respondents seeing self-censorship as present and serious rose from $13.3 \%$ in 2001 to $39.0 \%$ in 2011 . (3)

However, self-censorship is notoriously difficult to prove. Suspected attempts to enforce self-censorship within one's news organisation were never admitted as such, and it is difficult for observers to prove with certainty whether questionable treatment of a news story is politically motivated or simply a wrongheaded judgment. Besides, self-censorship is difficult to pinpoint because it may not be needed. Through resource allocation, adjusting the routines of news operations, and the production of informal norms and tacit rules within newsrooms, news organisations can end up producing largely pro-government content without conscious self-censorship.

Theoretically, Jansen (1988) developed the concept of constitutive censorship to refer to censorship resulting from how human communities establish rules and norms of discourse that delimit what can and cannot be said. Au (2017) applied the notion to examine how political biases are produced through newsroom routines and practices, such as authority supremacy (i.e. to take whatever the authorities say as valid), novice conformity (i.e. the tendency for new journalists to conform to superiors), and enhanced non-agenda setting (i.e. to avoid setting the media's own agenda based on independent news judgment). These norms and practices were established within newsrooms over time. Their overall consequence is the marginalisation of critical and in-depth reporting of important and sensitive matters.

\section{Counteracting forces and the paradox of political economy}

Despite the embedding of the mainstream media into the political economic structure, the demise of press freedom was incomplete because of the presence of counteracting forces. One of the most important counteracting forces is journalistic professionalism. Historically, the Hong Kong media took up the liberal conception of journalistic professionalism as their legitimating creed in the 1980s. Journalists see themselves as autonomous agents serving the public interest rather than the interests of political and economic power (Chan, Lee, and So 2012). They saw the provision of timely and accurate information as the most important role of the media, followed by helping the public to understand government policies and monitoring the power holders (So and Chan 2007).

Professionalism is also the dominant discourse within many newsrooms. In fact, suspicious acts of self-censorship were often couched in professional and/or technical terms. For instance, during the Umbrella Movement, Television Broadcasting (TVB) aired a story in the early morning of 15 October 2014 showing seven police officers beating a protester. The voice-over was later revised to the effect of not explicitly describing the police as "beating and kicking" the protester. Facing public outcry, the news director of TVB claimed that the original voiceover was not "objective." In other words, the discourse of professionalism was employed to justify a controversial decision. However, as long as professionalism remains the dominant discourse, it means that frontline journalists can also use professionalism to argue against their superiors (Lee and Chan 2009).

Market concerns constituted another potential counteracting force. Most Hong Kong media outlets are commercial entities. Although it was noted that some owners may not care too much if their media organisations are highly profitable or not, losses incurred by media businesses would still constitute "costs" that cannot be totally ignored. Media organisations have the incentive to refrain from the most conspicuous forms of self-censorship because the latter could undermine credibility. Therefore, for a long period of time after the handover, some mainstream media remained highly critical of the SAR government even as they became docile when covering China. Journalists also acknowledged that self-censorship through tone adjustment was more common than through the more unjustifiable move of totally ignoring certain news stories (Chan et al. 2012).

Moreover, as long as a substantial proportion of Hong Kong citizens hold pro-democracy views, there would be a market for such ideas and information. Apple Daily is the most obvious example of a media outlet adopting the pro-democracy stance as their "marketing position." Another example is radio phone-in talk shows on public affairs. At least in the first decade after the handover, radio talk shows attracted a substantial audience and constituted an important channel for the voicing of highly critical views (Lee 2014).

The existence of even a couple of relatively daring outlets has significant implications for the media system. Their presence helps push the boundary

3. The figures came from the author's own analysis of data collected by the School of Journalism and Communication at the Chinese University of Hong Kong. 
Table 2 - Performance of i-cable 2001-2017

\begin{tabular}{|c|c|c|c|c|c|}
\hline \multirow[t]{2}{*}{ Year } & \multicolumn{3}{|c|}{ i-cable } & \multicolumn{2}{|c|}{$\begin{array}{l}\text { Operating profits of Wharf Holdings } \\
\text { by geographical location }\end{array}$} \\
\hline & Cable TV subscribers & Internet service subscribers & Profit & Hong Kong & China \\
\hline 2001 & 560,000 & 160,000 & 167 & --- & --- \\
\hline 2002 & 605,000 & 225,000 & 117 & --- & --- \\
\hline 2003 & 656,000 & 258,000 & 220 & --- & --- \\
\hline 2004 & 702,000 & 291,000 & 284 & --- & --- \\
\hline 2005 & 738,000 & 320,000 & 583 & --- & --- \\
\hline 2006 & 786,000 & 328,000 & 181 & --- & --- \\
\hline 2007 & 882,000 & 306,000 & 183 & 8,445 & 876 \\
\hline 2008 & 917,000 & 267,000 & $(111)$ & 7,438 & 111 \\
\hline 2009 & $1,000,000$ & 249,000 & $(40)$ & 7,605 & 918 \\
\hline 2010 & $1,101,000$ & 228,000 & (267) & 7,977 & 1,228 \\
\hline 2011 & $1,106,000$ & 218,000 & (179) & 8,843 & 2,512 \\
\hline 2012 & $1,089,000$ & 201,000 & $(278)$ & 10,121 & 4,019 \\
\hline 2013 & $1,060,000$ & 196,000 & (93) & 9,882 & 3,362 \\
\hline 2014 & $1,002,000$ & 186,000 & $(140)$ & 11,549 & 2,701 \\
\hline 2015 & 851,000 & 171,000 & (233) & 11,409 & 3,406 \\
\hline 2016 & 909,000 & 156,000 & (313) & 12,780 & 4,234 \\
\hline $2017^{* *}$ & 850,000 & 149,000 & (363) & 11,447 & 9,124 \\
\hline
\end{tabular}

Notes: Information is derived from the annual financial reports of $\mathrm{i}$-cable and Wharf Holdings (HK). Figures in the last three columns are in million Hong Kong dollars. Bracketed figures represent losses. ${ }^{* *}$ Wharf sold i-cable to a new group of investors in mid-2017.

of acceptable public discourse. They play the role of the "first publishers" of critical viewpoints and sensitive information. Once certain views and information are publicised, other media outlets find it more difficult to ignore the matter. In other words, the presence of a few relatively daring outlets could effectively maintain a degree of heterogeneity in public discourse.

In sum, many studies saw the political economic structure of the Hong Kong media system as the root of the city's "problem of press freedom." Yet professionalism, market forces, and a certain degree of diversity within the media system helped counter political pressure. Such an analytical framework remains applicable to the current situation. But there have also been more recent changes in the political economy of the Hong Kong media, especially in relation to the market and technological environment for media businesses.

\section{Changing media businesses and the entrance of Chinese capital}

As noted earlier, the presumption underlying the politics of media owner co-option is that owning a Hong Kong media outlet constitutes a form of symbolic capital useful for business people when they enter the mainland. This implies a cost-benefit calculation with two basic questions: 1) How profitable or costly is it to run a specific Hong Kong media outlet? 2) To what extent is being a Hong Kong media owner actually tied to or capable of bringing about profits in the mainland?

Answers to these two questions can vary over time and across media firms. This section uses Cable TV and Ming Pao as two illustrative cases. Both are important media outlets: Cable TV is the first pay multichannel television service provider in Hong Kong and one of only four television service providers in the city in 2018, ${ }^{(4)}$ whereas Ming Pao has been a prominent-in terms of circulation, credibility, and influence-elite-oriented newspaper in the city. Related to the concern of political economy, Cable TV is an example of a media company owned by a bigger conglomerate running a wide range of businesses, whereas Ming Pao belongs to a larger media corporation. Combined together, they can shed light on the changing incentive structure that media owners have to face.

\section{Cable TV}

In 1985, the Hong Kong government announced the plan to introduce multichannel cable television into Hong Kong as part of a plan to strengthen the city's information infrastructure (Lau 1988). Given the huge initial investment needed, the government offered the operator monopoly status for three years (which was later extended to six years). Wharf Cable Ltd., owned by Wharf Holdings (HK), won the bid and became the first pay multichannel television operator in Hong Kong in October 1993.

The development of the business was slow. Cable TV withstood a loss of HK\$650 million in 1995 and HK\$580 million in 1996. The government extended the monopoly status of Wharf Cable and started to allow it to sell advertising, originally banned because of opposition from the free television broadcasters. Wharf Cable broke even in February 1998. Then, in August 1999, the SAR government invited the company to submit an application for operating telecommunication services over its cable network. The company was renamed "i-cable" and started providing Internet services in February 2000 (Lee 2007).

The offering of Internet service helped stabilise the business of the company. i-cable consistently made profits between 2001 and 2007 (Table 2). Meanwhile, the government opened up the pay television market. NOW

4. The other three are Television Broadcasting Ltd. (free-to-air), ViuTV (free-to-air), and NOW TV (pay service).ViuTV and NOW TV are owned by the same corporation. 
Francis L. F. Lee - Changing Political Economy of the Hong Kong Media

Table 3 - Media Chinese International Ltd.'s profits/losses by region, 2009-2017

\begin{tabular}{|l|c|c|c|c|c|c|c|c|c|}
\hline & 2009 & 2010 & 2011 & 2012 & 2013 & 2014 & 2015 & 2016 & 2017 \\
\hline HK \& China & 3.8 & 5.3 & 9.2 & 9.7 & 6.3 & 4.6 & $(1.8)$ & $(3.8)$ & $(0.6)$ \\
\hline Southeast Asia & 52.6 & 64.4 & 72.7 & 70.0 & 66.5 & 48.4 & 39.6 & 28.3 & $(3.0)$ \\
\hline North America & $(0.4)$ & 3.5 & 1.5 & $(0.0)$ & 0.9 & 0.3 & $(1.0)$ & $(1.1)$ & $(2.5)$ \\
\hline Total & 55.8 & 75.0 & 85.8 & 81.5 & 78.0 & 57.1 & 43.1 & 25.9 & $(3.7)$ \\
\hline
\end{tabular}

Notes: A fiscal year for the company begins in April, i.e. 2017 refers to April 2017 to March 2018. Figures are sectoral profits before tax in million USD. Bracketed figures are losses. "Total" includes profits or losses accrued through "travel and travel-related services," which are not broken down geographically. Information was derived from the company's annual reports.

TV, owned by telecommunication company PCCW, began broadcast in September 2003. TVB also offered its own pay television service in 2004 As Table 2 shows, 2003 and 2004 marked the peak of Cable TV's profitability.

This is not the place to go into the details of the pay TV business. Suffice it to note that Hong Kong is a small market with only about 2.4 million households, and the services offered by different pay TV providers are similar to each other. Since the 2000s, pay TV services also faced the challenge of the Internet, which offers virtually unlimited amounts of often free audiovisual entertainment. i-cable began to sustain a loss in 2008. The losses reached HK\$313 million for i-cable and HK\$277 million for its TV operations in 2016. Finally, after nine years of continual losses, Wharf Holdings (HK) Ltd. decided not to continue to support the operation of i-cable and sold it to a new group of investors in April 2017.

It might seem normal for Wharf to offload an unprofitable business. In fact, the losses of i-cable increased further to HK\$363 million in 2017. But following the earlier discussion, one might ask why Wharf was unwilling to continue to take the loss if owning Cable TV could bring about benefits in the mainland. In fact, Wharf's businesses in both Hong Kong and the mainland are huge and growing (Table 2). Its operating profits in the mainland rose from HK\$918 million in 2009 to HK\$4,234 million in 2016. Its operating profits in Hong Kong also reached HK\$12,780 million in 2016. In other words, in 2016, the loss of i-cable is less than $2 \%$ of the profits Wharf derived from Hong Kong and the mainland. When one explains Wharf's decision to offload i-cable, the worsening business environment for pay television is a partial answer. One also needs to consider how the cost-benefit calculation associated with owning a Hong Kong media outlet might have changed.

\section{Ming Pao}

Starting as a tabloid in the late 1950s, Ming Pao became an influential middle-class oriented Chinese daily by the 1980s (Cheung 2007). Originally owned by the famous novelist and essayist Louis Cha, the paper was sold to Hong Kong businessman Yu Punhoi in 1991 and then to Malaysian businessman Tiong Hiew King - founder and owner of the timber company Rimbunan Hijau Group_-in 1995. Tiong entered the media business when he purchased Malaysia's Chinese newspaper Sin Chew Daily in 1988 one year after the paper was closed down by prime minister Mahathir amidst severe racial conflicts. He bought Guangming Daily in 1992 and then became the main shareholder of Yayasan Nanyang Press (which owns Nanayang Siang Pau and China Press) in 2006. In 2008, Tiong established Media Chinese International Ltd. by combining Ming Pao with his newspaper businesses in Malaysia. The move even brought him the nickname "Asia's Rupert Murdoch." (5)
Tiong thus differs from Peter Woo of Wharf in that he has a relatively bigger interest in the media business itself. Notably, he has the experience of running relatively independent newspapers in the context of authoritarian countries. His Chinese dailies in Malaysia are, on the whole, more neutral on political matters when compared to the Malay and Anglophone press in the country, which tend to be more explicitly pro-government (Abbott and Givens 2015). In one sense, Ming Pao's approach of "intensified objectivity" (Lee and Lin 2006) after the handover-i.e. to emphasise or even over-emphasise objectivity and neutrality in order to avoid political risks yet without turning oneself totally into a government mouthpiece-is similar to the performance of the Malaysian Chinese newspapers under Tiong.

With numerous Chinese-language media outlets in hand, Tiong was interested in expanding not only his timber business but also his media business in China. Ming Pao collaborated with Guangzhou Daily in the mid-2000s to publish the North American edition of the latter newspaper (Fung 2007). The 2008 annual report of Media Chinese International Ltd. stated that the company had started to develop their markets in "Chinese communities beyond their existing regional/local markets" through franchised magazines. In November 2009, the company purchased $25.4 \%$ of the shares of ByRead Inc., then the biggest mobile reading platform in the mainland with more than 25 million users at that time.

Despite such efforts, the corporation has failed to truly develop a substantive business presence in mainland China due to tight control of media entrance by the Chinese government. By the end of year 2017, on the website of the corporation, there are only three items listed under the category of businesses in the mainland: 1) the mainland edition of the British car magazine Top Gear, 2) the entertainment information website hihoku.com, and 3) mingwatch.com, a website providing information about watches.

As Table 3 shows, the Hong Kong and China sector of Media Chinese International Ltd. has not been particularly profitable. Between 2009 and 2014, the profits generated from the HK/China region were typically only about $10 \%$ of the profits the corporation obtained from Southeast Asia. Since the early 2010s, the profits from Hong Kong and China declined continually, and losses were registered in each year between 2015 and 2017 (though the corporation's performance in Southeast Asia also suffered). Against this background, right after Chinese e-commerce giant Alibaba purchased SCMP in December 2015, there were rumours of Alibaba's plan to purchase Ming Pao. A Malaysian media observer wrote:

From the business perspective, if Alibaba offers a good price (which is not difficult), selling the hot potato of Hong Kong's (and North America's) Ming Pao is not bad for Media Chinese International Ltd.

5. "Tiong Hiew King: The China dream of a Chinese merchant from the Southern sea," op. cit. 
(...). China in 2015 is no longer China in 1995. Tiong Hiew King's dream of being Asia's Murdoch is already dying. ${ }^{(6)}$

Alibaba's rumoured purchase of Ming Pao did not materialise. But the emergence of the rumour and passages such as the above do point to a general perception that, into the mid-2010s, owning a Hong Kong media outlet is no longer as "sensible" as it was.

\section{Changing incentive structure and the entrance of Chinese capital}

The obvious first point to note from the above discussions of Cable TV and Ming Pao is the increasingly adverse business environment for the Hong Kong media. Both companies, and in fact other media organisations including dominant players such as TVB, have witnessed declining profits or increasing losses in the past several years. A main reason for the decline is the digital transformation of the media system, an issue to be discussed in the next section. The straightforward implication here is that the opportunity costs associated with owning a media organisation have increased.

A second point worth noting is that the mainland Chinese media market has remained largely closed to outsiders. China's entrance into the World Trade Organisation in 2001 at one point led to anticipation of the gradual opening up of the media market. But 15 years later, the distribution of even entertainment content ranging from Hollywood movies to Korean TV dramas is still subjected to tight control. The policy is aimed not only at fending off ideological infiltration, but also at building China's own media industries with a view to strengthening the country's soft power (Su 2014). Hong Kong media organisations originally hoping to extend their business to the mainland found themselves facing a brick wall.

The two considerations point to the increasing costs of obtaining the symbolic capital of "being a Hong Kong media owner." On the other side of the equation, one might question if the value of "being a Hong Kong media owner" has declined. Although it is difficult to directly examine the logic of exchange in the Chinese business field, we can at least raise a question by comparing the 1990s to the 2010s. While many Hong Kong corporations were only starting to enter the Chinese market in the 1990s, 20 years later, they have already established their foothold in the mainland, as illustrated by the huge growth in profits in the case of Wharf. Influential business people in Hong Kong have established their alliance with the Chinese state, to the extent that they can even bypass the SAR government and communicate with the Central Government directly to seek their own interests (Fong 2014). If certain symbolic capital was needed for Hong Kong business people in the 1990s to obtain social and political capital in the mainland, is it possible that symbolic capital is no longer needed when they already have social and political capital?

Meanwhile, the political pressure associated with owning a Hong Kong media organisation may have become more severe in recent years. Among Hong Kong mainstream media, both Cable TV and Ming Pao have been regarded as relatively liberal. Cable TV's China news team, in particular, had received critical acclaim for their in-depth and occasionally daring coverage of China. Yet the possibility of a pro-China businessman holding a relatively liberal media outlet is premised on both the state's level of tolerance and the businessman's bargaining power. In the most recent years, as the political situation in Hong Kong has worsened and as the Chinese government has tightened ideological control over the media and society (Zhao 2016), the state's tolerance level could have been declining.
The arguments in the previous paragraphs may contain some speculative elements, but generally speaking, there are enough reasons for us to state that the incentive structure was shifting in a direction that makes owning Hong Kong media less and less attractive to a Hong Kong business person. It does not mean that no one is entering the field, but the general trend is that Hong Kong (and regional) business people are leaving the field, whereas mainland Chinese capital is entering the scene. Alibaba's purchase of SCMP and Shanghai media mogul Li Ruigang's purchase of shares of TVB were the most eye-catching moves.

Since the trend is recent, we have little knowledge at this point about the motivations and constraints behind the entrance of Chinese capital into the Hong Kong media scene. It is also too early to judge how big a difference "Chinese capital ownership" would make. Yet just as a matter of fact, since the Cable TV transaction in mid-2017, nine out of 26 mainstream media outlets in Hong Kong have mainland Chinese stakes (HKJA 2017: 5). (7)

\section{Digital transformation and its implications}

A discussion of the political economy of contemporary media cannot ignore the changes brought about by digital technologies. Digital media are not so much content-producing institutions as platforms on which both old and new media institutions operate. Digital media also have become the primary platforms through which citizens acquire the news. In an online survey by the Reuters Institute for the Study of Journalism in 2017, 84\% of Hong Kong respondents named "online media" (including social media) as their sources of news, and $43 \%$ named online media as their "main source" of news (Lee et al. 2017).

The following further discusses the implications of digitalisation on the news business. The discussion then turns to the new "online news outlets," with an emphasis on how political economic forces are shaping the online media landscape in Hong Kong.

\section{Business problems of conventional media in the digital world}

Traditionally, media organisations operate by selling bundled content to the audience and audience attention to advertisers. When the Internet arrived in the 1990s, many news organisations began to establish their websites. In an environment where free content was widely available, most news organisations decided not to charge for online subscriptions. At the same time, corporations remained unsure about the efficacy of online advertising. Hence the conventional business model did not work in the online world: news organisations did not charge the audience for content, and the online attention they garnered did not generate much advertising revenue.

Digital advertising has grown substantially in more recent years with the further development of Internet and mobile technologies. According to statista.com, total revenue in Hong Kong's digital advertising market amounted to US\$998 million in 2018 and is expected to surpass US\$1,800 million in 2022. ${ }^{(8)}$ But as digital advertising has matured, the digital media

6. Teck-Peng Chang 莊迪澎, “張曉卿會脫售明報嗎?” (Tiong Hiew King hui tuoshou Mingbao ma?, Will Tiong Hiew King sell Ming Pao?), Promethean Fire Review, 18 December 2015, http://www.pfirereview.com/20151218/ (accessed on 10 November 2017).

7. In addition to registered ownership, there are repeated rumours about mainland Chinese capital funding the purchase of media outlets by Hong Kong business people, though the rumours cannot be substantiated.

8. https://www.statista.com/outlook/216/118/digital-advertising/hong-kong\# (accessed on 14 August 2018). 
Francis L. F. Lee - Changing Political Economy of the Hong Kong Media

Table 4 - Revenue breakdown of Next Media Ltd. (Next Digital since October 2015), 2010-2017

\begin{tabular}{|l|c|c|c|c|c|c|c|c|c|}
\hline & 2010 & 2011 & 2012 & 2013 & 2014 & 2015 & 2016 \\
\hline Sales of newspapers & 783 & 744 & 665 & 608 & 496 & 417 & 355 & 308 \\
\hline Sales of books/magazines & 260 & 239 & 199 & 161 & 134 & 89 & 51 & 31 \\
\hline Newspaper advertising & 1533 & 1614 & 1544 & 1325 & 987 & 665 & 455 & 343 \\
\hline Books/Mag. advertising & 644 & 724 & 688 & 627 & 513 & 309 & 106 & 45 \\
\hline Printing services & 240 & 234 & 220 & 184 & 179 & 189 & 167 & 173 \\
\hline Internet businesses & 13 & 47 & 157 & 364 & 648 & 660 & 650 & 594 \\
\hline $\begin{array}{l}\text { \% of total accounted for by Internet } \\
\text { businesses }\end{array}$ & $0.4 \%$ & $1.3 \%$ & $4.5 \%$ & $11.1 \%$ & $21.9 \%$ & $28.3 \%$ & $36.4 \%$ & $39.8 \%$ \\
\hline
\end{tabular}

Notes: A fiscal year for the company begins in April, i.e. 2017 refers to April 2017 to March 2018. Internet businesses include advertising income, subscription, and content provision. Figures are in million HKD and come from annual reports of the company.

environment has also been tremendously transformed. Social media (e.g. Facebook) and search engines (e.g. Google) constitute the most important platforms and gateways through which people access content. With access to "big data" and thus the ability to push highly personalised ads to users, social media sites and search engines are obtaining a substantial proportion of the digital advertising revenues. According to a report by Digital in Asia, the total digital ad revenues in the Asia Pacific amounted to US\$8.74 billion in the first quarter of 2018. Facebook and Google accounted for US\$5.70 billion, i.e. more than $60 \%$ of the total. (9)

In addition, digital and social media provided the platform for the emergence of new types of small-scale media outlets that can nonetheless attract a sizeable niche audience. In Hong Kong, the Facebook pages of some KOLs (Key Opinion Leaders) can have more than 100,000 fans and followers. Since some KOLs have very distinctive interests and/or content focuses, they can be attractive venues for advertisers who want to reach specific audience niches. The result is the further diminishing of advertising expenditure on conventional media organisations.

Apple Daily, or Next Digital (or Next Media before October 2015) as a whole, is arguably the most illustrative case when considering how digitalisation has affected the business performance of a conventional news organisation. The company is illustrative because it was highly aware of the need to face the digital challenge. It started offering Animated News online in 2009-consisting of short audio-visual news clips, often about sensational stories and with frequent use of graphics and animation. While the product might be ethically controversial, it was once regarded as highly successful in attracting a huge online audience (Ma, Lau, and Hui 2014).

However, this endeavour did not prevent the company from facing a sharp decline in its business. As Table 4 shows, the revenue Next Digital obtained from its online businesses did increase substantially between 2011 and 2014. But the growth almost stopped in 2015, and even declined in 2016 and 2017. Besides, the growth in Internet revenue was far from enough to compensate for the drop in sales of print media and print advertising revenue: the total revenue derived from the first four categories of Table 4 dropped from HK\$3,321 million in 2011 to HK\$967 in 2016. The sharp decline forced the company to close down the magazines Sudden Weekly and Face in 2015 and 2016 respectively. In March 2018, Next Magazine became digital only.

Beyond conventional media companies, the lack of a sustainable business model has also affected the development of new online media outlets. For example, online news outlet The Initium, established in 2015, had to cut down its staff size in April 2017 from about 90 to around 30. ${ }^{(10)}$ One direct consequence of the media's struggle for survival is the dwindling resources news organisations can expend on in-depth and/or investigative reporting. The worsening business environment thus has important implications for the media's ability to play a watchdog role and monitor power holders.

\section{From Internet alternative media to parallel echo chamber}

Certainly, while the Internet and social media have created huge challenges to the news business, they have also reduced distribution and reproduction costs and thus allowed small-scale, low-cost media outlets to emerge. In Hong Kong, the Internet has facilitated the development of online alternative media and some small-scale news operations.

The development of online alternative media is particularly significant where freedom of the press is concerned. Alternative media can be defined as media outlets that challenge the mainstream media's power to define reality (Couldry and Curran 2003). Alternative media outlets are structurally independent of dominant political and economic institutions, and they typically espouse an oppositional ideology. In Hong Kong, the first wave of online alternative media emerged mainly in the form of online radio after the 2003 July 1 protest. While many of them did not survive for long due to financial reasons, a second wave of alternative media, mainly in the form of news-cum-commentary websites, emerged around 2012 (Leung 2015).

There have not been systematic studies of the financial and organisational aspects of alternative media outlets in Hong Kong. But the cost of operating alternative media can be as low as around HK\$1 million per year, as in the case of Inmedia Hong Kong, a commentary website established in 2005. Some alternative media outlets have a somewhat larger staff size. The Stand News, one of the most prominent alternative media outlets in the city, had 16 employees in 2015. But the monthly operational cost was still only HK\$500,000 at the time. ${ }^{(11)}$

Alternative media are the sites where critical viewpoints are published and politically sensitive topics are discussed. As opposed to conventional

9. Tom Simpson, "A duopoly of convenience: Facebook \& Google tap new growth in APAC," Digital in Asia, 25 June 2018, https://digitalinasia.com/2018/06/25/the-duopoly-in-apac-google-facebook-grow-ad-revenue-40-in-2018/ (accessed on 5 August 2018).

10. “端傳媒裁員 50 人接離職信” (Duanchuan mei caiyuan 50 ren jie lizhixin, The Initium lays off staff, 50 people receive dismissal letter), Ming Pao, 8 April 2017.

11. “要眾籌不要金主, 讓新聞回到沒有干預的樣子”(Yao zhongchou buyao jinzhu: Rang xinwen huidao meiyou ganyu de yangzi, Crowdfunding instead of money-boss, let the news return to what it looks like without intervention), The Inititum, 11 August 2015, https://theinitium.com/article/20150811-hongkong-mediacrowfunding/ (accessed on 25 August 2018). 


\begin{tabular}{|c|c|c|c|c|}
\hline Type & Name & $\begin{array}{c}\text { Year of } \\
\text { establishment }\end{array}$ & $\begin{array}{c}\text { No. of page likes } \\
\text { on Facebook as } \\
\text { of } 15 \text { January } \\
2018\end{array}$ & Remarks \\
\hline $\begin{array}{l}\text { General interest } \\
\text { news media }\end{array}$ & $\begin{array}{l}\text { HK01.com } \\
\text { The Initium } \\
\text { Bastille Post }\end{array}$ & $\begin{array}{l}2016 \\
2015 \\
2013\end{array}$ & $\begin{array}{c}434,279 \\
243,641 \\
1,018,357\end{array}$ & $\begin{array}{l}\text { Established by businessman and former owner of Ming PaoYu Punhoi; } \\
\text { employing more than } 600 \text { staff at the time of writing. } \\
\text { Established with investment by a banker of mainland origin in 2015, } \\
\text { targeting the Greater China and overseas Chinese audience. } \\
\text { Founded by Sing Tao News Corporation Ltd. and its former CEO } \\
\text { Lo Wing Hung. }\end{array}$ \\
\hline Alternative media & $\begin{array}{l}\text { Inmedia HK } \\
\text { The Stand News } \\
\text { Passion Times }\end{array}$ & $\begin{array}{l}2005 \\
2014 \\
2012\end{array}$ & $\begin{array}{l}487,119 \\
220,739 \\
409,862\end{array}$ & $\begin{array}{l}\text { Formed by a group of activists and academics and closely associated with } \\
\text { several social movements in Hong Kong. } \\
\text { Formerly The House News, which was closed down in July } 2014 \text { with founder } \\
\text { Tony Choi claiming to have been facing severe political pressure; Choi and key } \\
\text { staff of The House News founded The Stand News in December } 2014 \text {. } \\
\text { Operated by the localist political group Civic Passion. }\end{array}$ \\
\hline $\begin{array}{l}\text { Pro-government } \\
\text { Facebook pages }\end{array}$ & $\begin{array}{l}\text { HKG Pao } \\
\text { Silent Majority } \\
\text { Speak Out HK }\end{array}$ & $\begin{array}{l}2015 \\
2013 \\
2013\end{array}$ & $\begin{array}{l}102,568 \\
170,227 \\
315,469\end{array}$ & $\begin{array}{l}\text { Owned by Chow Yung, founder of the pro-government group Silent Majority } \\
\text { for Hong Kong. } \\
\text { Operated by the pro-government group Silent Majority for Hong Kong. } \\
\text { Funded by the Hong Kong United Foundation, which has close ties to C.Y. } \\
\text { Leung. Chief Executive of Hong Kong from } 2012 \text { to } 2017 \text {. }\end{array}$ \\
\hline
\end{tabular}

news media, many of the alternative media prefer advocacy over the norms of objectivity and neutrality. Empirical research has shown that online alternative media consumption is related to more critical views toward the government, stronger perceptions of self-censorship in the mainstream media, and higher levels of protest participation (Leung and Lee 2014). These media outlets thus help maintain and expand the range of public discourse available to citizens.

Nevertheless, online alternative media and other small-scale online news outlets have several interrelated limitations. First, the lack of resources means that many of them do not engage in much original news reporting. They often focus on publishing commentaries and repackaging the news offered by conventional media, but the latter practice only adds to the plight of the conventional news organisations.

Second, the pro-establishment forces have set up a number of Facebook pages for the circulation of pro-government information and discourse surrounding key public issues, with Silent Majority for Hong Kong, HKG Pao, and Speak Out Hong Kong among the most prominent ones (see Table 5). Backed by the superior resources of the pro-establishment forces and often adopting polemical rhetoric, these pages often obtain levels of engagement-in terms of likes, shares, and comments attracted by their postseven higher than those obtained by the critical alternative media outlets during heated controversies. ${ }^{(12)}$

Third, with the presence of both online alternative media and pro-government outlets, and given how the Internet has facilitated heightened degrees of selective exposure (Sunstein 2017), media outlets on both sides are likely to reach mainly the supporters on their own side. The oppositional views publicised through the online alternative media are therefore unlikely to be able to influence the public at large. Instead, as Chan and Fu (2017) illustrate, when the online outlets on the two sides of the political divide formed into distinctive clusters, public opinion would become more polarised, i.e. the outlets only succeeded in reinforcing the views of their supporters.
Certainly, the latter phenomenon happens not only in Hong Kong. What Chan and Fu (2017) illustrate is the implication of the general phenomenon of cyberbalkanisation, i.e. the segregation of the Internet into small groups with shared interests and views. For this article, the important point is that cyberbalkanisation is not a "natural" phenomenon arising merely out of people's tendency toward selective exposure. In Hong Kong, while the state can hardly eliminate the online alternative media, its supporters have attempted to minimise the influence of alternative media through creating their own outposts, resulting in a balkanised cyberspace where the circulation of anti-government views becomes restricted.

\section{Concluding discussion}

This article reviewed the changing political economy of the Hong Kong news media in the first two decades after the handover. The mainstream media remain deeply embedded in the web of state-business relationships. As with 20 years ago, many media owners are business people having vast interests in the mainland. Yet ownership control does not entail constant intrusion into newsroom operations. The tug-of-war between political pressure and journalistic professionalism persists to the present and is likely to continue.

Nonetheless, the political economic structure is not fixed and unmoving. It is argued that, while business tycoons have established their footholds in China, "being a Hong Kong media owner" may no longer be as valuable as it was. At the same time, due to both social and technological changes, the media business is facing huge challenges. The opportunity costs of running a Hong Kong media organisation have increased, thus further reducing the incentives for Hong Kong business people to own media organisations. The

12. TANG, Gary Kin-Yat 鄧鍵一，“從七警事件看網上親建制輿論” (Cong qijing shijian kan wangshang qinjianzhi yulun, Analysing pro-establishment public opinion through the seven police officers controversy), Ming Pao, 27 April 2017 
development has paved the way for the entrance of Chinese capital into the Hong Kong media scene.

Writing in the early post-handover years, Chin-chuan Lee (2000: 291) has noted that "the impact of the new political economy on media structure and content has been uneven and paradoxical," because "economic concerns of the media create a political space for their workers to operate, to breathe, and even to defect or resist state structure." Two decades after the handover, market concerns as a counteracting force, while not having disappeared completely, seem to have weakened substantially.

The popularisation of the Internet and social media once led to much optimistic discourse about the power of new information technologies to promote freedom of information. But in recent years, more scholars have noted the limitations or even anti-democratic tendencies of social media (Sunstein 2017) and how authoritarian countries have developed sophisticated methods to tame the Internet. MacKinnon (2013) has coined the term "network authoritarianism" to refer to the ways China controls digital media through a mixture of practices including censorship, astroturfing, supporter mobilisation, monitoring of online opinions, and so on. The Chinese government may not be able to employ its full repertoire of Internet control in Hong Kong, but the pro-establishment camp has drawn upon its superior resources to establish a strong online presence.

This article thus explains the decline in press freedom in Hong Kong from a political economy perspective. In the foreseeable future, two issues are especially worthy of attention. The first is whether the entrance of Chinese capital into the Hong Kong media scene will continue, and what the consequences of the trend are. Whether mainland capital is different from or worse than Hong Kong capital for the free press is after all an empirical question. Yet it might be argued that, compared with mainland Chinese business people, Hong Kong and Southeast Asian tycoons are less likely to turn their media outlets into explicit propaganda machines. Hong Kong business tycoons, who belong to the local society, might be more sensitive toward the "tradition of press freedom" in the city. Their "political mission," as commonly understood, was to ensure that their media organisations would not step outside the boundaries of acceptability. Hence there is still a distinction between conservative mainstream newspapers and newspapers directly sponsored by the CCP, such as Wen Wei Po and Ta Kung Pao. The question is whether owners from mainland China would carry a dif- ferent "political mission" and hold a fundamentally different understanding of the press, and whether they will change the rules and norms of newsroom operation.

Second, the continual evolution of the digital media environment will have important implications for freedom of expression in the city. Barring extreme and radical measures, the Chinese and Hong Kong governments will have to live with the existence of a free Internet in Hong Kong. Yet that does not mean that the governments cannot strengthen their attempts to control public opinion through extending some of the means of Internet control in the mainland to the city. For example, in the prelude to the Umbrella Movement, the emails of one key proponent of the occupation campaign were leaked. The event hinted at online surveillance by the state. Some observers have expressed the worry that the Chinese and Hong Kong governments will expand their surveillance work in the city (Tsui 2015).

Finally, it is worth noting that press freedom is impossible without the presence of freedom of speech in society at large. As stated at the beginning, it is beyond the scope of this article to discuss this broader problematic. Suffice it to reiterate the point that how the Chinese and Hong Kong governments shape the legal parameters for free speech in the city, such as through the proposal to introduce China's national anthem law to Hong Kong and the possible re-initiation of national security legislation, constitutes another issue of concern.

Nevertheless, to end the article on a less gloomy note, freedom of expression and of the press in Hong Kong is not totally dead. The struggles and negotiations for press freedom are still going on. It is up to professional journalists to conduct their local resistance within newsrooms, up to civil society groups to enact online alternative media to communicate alternative views and information, and up to ordinary citizens to offer support to those media outlets that are willing to hold onto their professional principles and challenge the powerholders.

\section{Francis L. F. Lee is Professor in the School of Journalism and Communication at the Chinese University of Hong Kong. School of Journalism and Communication, Room 206-207, Humanities Building, New Asia College, The Chinese University of Hong Kong, Shatin, N.T., Hong Kong (francis_lee@cuhk.edu.hk).}

Manuscript received on 13 April 2018. Accepted on 24 July 2018. 


\section{References}

ABBOTT, Jason, and John Wagner GIVENS. 2015. "Strategic Censorship in a Hybrid Authoritarian Regime? Differential Bias in Malaysia's Online and Print Media." Journal of East Asian Studies 15(3): 455-478.

AU, Ka-Lun 區家麟. 2017. 新聞自由的二十道陰影 (Xinwen ziyou de ershi dao yinying, Press freedom under 20 shades of grey). Hong Kong: Chinese University of Hong Kong Press.

CHAN, Chung-Hong, and King-Wa FU. 2017. "The Relationship Between Cyberbalkanization and Opinion Polarization:Time-Series Analysis on Facebook Pages and Opinion Polls During the Hong Kong Occupy Movement and the Associated Debate on Political Reform." Journal of Computer-Mediated Communication 22: 266-83.

CHAN, Joseph Man, and Chin-chuan LEE. 1991. Mass Media and Political Transition. New York: Guilford.

CHAN, Joseph Man, Francis Lap-Fung LEE, and Clement York-Kee SO. 2012. "Journalists in Hong Kong: A Decade after the Transfer of Sovereignty." In Lars Willnat and David Weaver (eds.), The Global Journalists in the $27^{\text {st }}$ Century. New York: Routledge. 22-35.

CHEUNG, Anne Shann-Yue. 2003. Self-censorship and the Struggle for Press Freedom in Hong Kong. The Hague, Netherlands: Kluwer Law International.

CHEUNG, Kwai-Yeung 張圭陽. 2007. 金庸與報業 (Jin Yong yu baoye, Jin Yong and the press). Hong Kong: The Commercial Press.

COULDRY, Nick, and James CURRAN (eds.). 2003. Contesting Media Power. Lanham: Rowman \& Littlefield.

FONG, Brian Chi-Hang. 2014. "The Partnership between the Chinese Government and Hong Kong's Capitalist Class: Implications for HKSAR Governance, 1997-2012." China Quarterly 217: 195-220.

FUNG, Anthony Ying-Him. 2007. "Political Economy of Hong Kong Media: Producing a Hegemonic Voice." Asian Journal of Communication 17(2): 159-71.

HONG KONG JOURNALISTS ASSOCIATION. 2015. Journalists Caught between Two fires: Hong Kong Media Faces Serious Harassment and Selfcensorship. Annual Report of the Hong Kong Journalists Association.

HONG KONG JOURNALISTS ASSOCIATION. 2017. Two Systems Under Siege: Beijing Turns the Screws on Hong Kong Media. Annual Report of the Hong Kong Journalists Association.

JANSEN, Sue Curry. 1988. Censorship: The Knot That Binds Power and Knowledge. New York: Oxford University Press.

LAU, Tuen-yu. 1988. "Introducing Cable Television into Hong Kong: Political and Economic Implications." Telecommunications Policy 12(4): 379-92.

LEE, Chin-Chuan. 1998. "Press Self-censorship and Political Transition in Hong Kong." Harvard International Journal of Press/Politics 3(2): 55-73.

LEE, Chin-Chuan. 2000. "The Paradox of Political Economy: Media Structure, Press Freedom, and Regime Change in Hong Kong." In Chin-Chuan Lee (ed.), Power, Money, and Media. Illinois: Northwestern University Press. 288-336.
LEE, Francis Lap-Fung. 2007. "Development of Pay Television in Hong Kong: History, Audience Consumption, and Challenges." Journal of Comparative Asian Development 4(2): 247-72.

LEE, Francis Lap-Fung. 2014. Talk Radio, the Mainstream Press, and Public Opinion in Hong Kong. Hong Kong: Hong Kong University Press.

LEE, Francis Lap-Fung, Joseph Man CHAN, Hsuan-Ting CHEN, Dennis KaKuen LEUNG, Antonis KALOGEROPOULOS, and Rasmus Kleis NIELSEN. 2017. Digital News Report Asia Pacific Supplement 2017. Oxford: Reuters Institute for the Study of Journalism.

LEE, Francis Lap-Fung, and Joseph Man CHAN. 2009. "The Organisational Production of Self-censorship in the Hong Kong Media." International Journal of Press/Politics 14: 112-33.

LEE, Francis Lap-Fung, and Angel Mei-Yi LIN. 2006. "Newspaper Editorial Discourse and the Politics of Self-censorship in Hong Kong." Discourse \& Society 17(2): 331-58.

LEUNG, Dennis Ka-Kuen. 2015. "Alternative Internet Radio, Press Freedom and Contentious Politics in Hong Kong, 2004-2014." Javnost-the Public 22(2): 196-212.

LEUNG, Dennis Ka-Kuen, and Francis Lap-Fung LEE. 2014. "Cultivating an Active Online Counter-public: Examining Usage and Political Impact of Internet Alternative Media." International Journal of Press/Politics 19(3): 340-59.

MA, Ngok. 2007. "State-press Relationship in Post-1997 Hong Kong: Constant Negotiation amidst Self-restraint." China Quarterly 192: 949-70.

MA, Wai-Kit, Hey-Yeung LAU, and Yuet-Hang HUI. 2014. "The 2014 Survey on News and Social Media Use." Media Digest. 12 September 2014. http://app3.rthk.hk/mediadigest/content.php?aid=1960 (accessed on 25 August 2018).

MACKINNON, Rebecca. 2013. Consent of the Networked. New York: Basic Books.

MOSCO, Vincent. 2009. The Political Economy of Communication. London: Sage.

MURDOCK, Graham. 1982. "Large Corporations and the Control of the Communications Industries." In Michael Gurevitch, Tony Bennett, James Curran, and Janet Woollacott (eds.), Culture, Society and the Media. London: Routledge. 114-47.

SO, Clement York-Kee, and Joseph Man CHAN. 2007. "Professionalism, Politics, and Market Force: Survey Studies of Hong Kong Journalists 19962006." Asian Journal of Communication 17(2): 148-58.

SU, Wendy. 2014. "Cultural Policy and Film Industry as Negotiation of Power: The Chinese State's Role and Strategies in Its Engagement with Global Hollywood, 1994-2012." Pacific Affairs 87(1): 93-114.

SUNSTEIN, Cass. 2017. \#Republic. Princeton: Princeton University Press.

TSUI, Lokman. 2015. "The Coming Colonization of Hong Kong Cyberspace: Government Responses to the Use of New Technologies by the Umbrella Movement." Chinese Journal of Communication 8(4): 447-55.

ZHAO, Suisheng. 2016. "The Ideological Campaign in Xi's China: Rebuilding Regime Legitimacy." Asian Survey 56(6): 1168-93. 